\title{
Peran karang taruna dalam mewujudkan tanggung jawab sosial pemuda sebagai gerakan warga negara
}

\author{
Febri Fajar Pratama ${ }^{a, 1 *}$, Rahmat ${ }^{\text {b,2 }}$ \\ a,b Departemen Pendidikan kewarganegaraan, Universitas Pendidikan Indonesia, Bandung Indonesia \\ ${ }^{1}$ febri.pratama@student.upi.edu*;2 rawides@yahoo.com
}

*korespondensi penulis

\begin{tabular}{ll}
\hline \multicolumn{2}{l}{ Informasi artikel } \\
\hline Sejarah artikel: & \\
Diterima & $: 03-04-2018$ \\
Revisi & $: 14-07-2018$ \\
Dipublikasikan & $: 31-10-2018$ \\
\hline
\end{tabular}

Kata kunci:

pemuda

tanggung jawab sosial

karang taruna

warga negara

pendidikan kewarganegaraan

\begin{abstract}
ABSTRAK
Generasi muda merupakan aset bangsa, namun banyak dari pemuda yang saat ini kurang memiliki rasa tanggung jawab sosial dalam dirinya. Selain melalui pendidikan, rasa tanggung jawab pemuda dapat diwujudkan melalui organisasi, salah satunya adalah Karang Taruna sebagai organisasi sosial berbasis kepemudaan yang memiliki peran penting dalam mewujudkan tanggung jawab sosial pemuda. Teknik pengumpulan data yang digunakan yakni wawancara, studi literatur, dokumentasi dan pengamatan (observasi). Dari hasil penelitian didapatkan bahwa Karang Taruna Nagasari memiliki konsep pembentukan tanggung jawab sosial dengan memaksimalkan potensi wilayah, pemberdayaan pemuda dan masyarakat, mengedepankan konsep berdikari untuk melahirkan entrepreneur muda, membuat program produktif secara kontinu dengan memperhatikan aspek lingkungan serta permasalahan sosial yang dihadapi masyarakat desa, khususnya mengenai kepemudaan, mengajak pemuda untuk peka terhadap lingkungan sosial, serta membantu sesama dengan tulus.

ABSTRACT

The young generation is a national asset, but many of the youth currently lack a sense of social responsibility in themselves. In addition to education, the sense of responsibility of youth can be realized through organizations, one of which is Youth Organization as a youth-based social organization that has an important role in realizing youth social responsibility. Data collection techniques used are interviews, literature studies, documentation, and observations. From the results of the study, it was found that the Nagasari Karang Taruna had the concept of forming social responsibility by maximizing the potential of the region, empowering youth and society, promoting a self-sufficient concept to create young entrepreneurs, making productive programs continuously by paying attention to environmental aspects and social problems faced by rural communities, especially regarding youth, invites youth to be sensitive to the social environment, and help others sincerely.
\end{abstract}

Keywords:

youth

social responsibility

youth organization

citizen

citizenship education

\section{Copyright (C) 2018 Febri Fajar Pratama \& Rahmat}

\section{Pendahuluan}

Generasi muda lahir sebagai bagian dari peradaban dunia. Semangat perubahan terhadap hal yang dianggap bertentangan dengan nilai-nilai luhur yang diyakini para pemuda menjadi landasan utama mereka dalam bergerak menentang sistem yang tidak sesuai. Sejarah membuktikan bahwa gerakan para kaum muda berhasil mempengaruhi semangat kebangsaan rakyat Indonesia untuk merdeka. Pergerakan yang dipelopori kaum muda tahun 1928 misalnya, dan kelahiran organisasi-organisasi kepemudaan yang bernafaskan semangat pemuda dengan istilah "jong” atau pemuda. Mereka pada akhirnya berhasil menekan para imperialis dan memaksa para kaum tua seperti Bung Karno kala itu untuk memproklamirkan kemerdekaan, meski pada saat itu Bung Karno lebih cenderung menekankan diplomasi daripada perang. 
Namun saat ini, dalam proses dan perkembangannya, pemuda menghadapi permasalahan sosial yang justru membuat semangat pemuda masa pra kemerdekaan yang dahulu sudah tidak nampak lagi pada pemuda saat ini. Terlepas dari pengaruh modernisasi dan juga globalisasi, hanya sedikit pemuda yang dapat berkontribusi dalam peranannya sebagai agen perubahan serta kontrol sosial, pun juga dengan hakikat mereka sebagai makhluk sosial, yang dalam etika politik makhluk sosial dijelaskan dalam salah satu dimensi politis manusia yang menekankan pada tanggung jawab atas tindakan-tindakan yang dilakukan, dimana suara hati menjadi pengingat bahwa dia sendirilah yang bertanggung jawab atas setiap hal yang dilakukan (Suseno, 2015). Tentunya, berdasarkan hakikat pemuda yang sadar bahwa mereka merupakan makhluk sosial, rasa tanggung jawab dapat dipupuk dengan baik melalui program-program yang dapat menjadi stimulus untuk menumbuhkan perasaan nasionalisme, patriotisme, rasa gotong royong, serta kepekaan sosial mereka, agar dikemudian hari permasalahan sosial dalam diri pemuda yang dapat menyebabkan dekadensi moral tidak meluas dan bahkan menjadi hal yang sulit ditanggulangi.

Dalam pelaksanaan pembinaan pemuda dalam membentuk rasa tanggung jawab sosial secara formal dapat dilakukan melalui institusi pendidikan. Salah satu upaya yakni dengan memberikan materi tentang pendidikan kewarganegaraan di setiap jenjang, dari tingkat dasar hingga perguruan tinggi. Pendidikan kewarganegaraan menekankan pada pembentukan karakter warga negara yang baik (good citizenship) dan bertanggung jawab. Tetapi tentu saja apa yang dipelajari di dalam ruang kelas hanya sebatas teori dan pemahaman saja. Sehingga fungsi pemberdayaan pemuda dalam mewujudkan tanggung jawab sosial di lingkungan masyarakat tidak dapat dilakukan secara optimal.

Dewasa ini pembinaan pemuda menjadi begitu krusial, hal tersebut tentunya sangat berpengaruh pada perkembangan bangsa Indonesia yang diperkirakan pada tahun 20202039 akan memiliki bonus demografi ketika usia produktif lebih banyak ketimbang usia yang sudah tidak produktif (Konadi \& Iba, 2011). Bonus demografi ini bisa saja menjadi pedang bermata dua, artinya bisa saja menjadi baik, bahkan bisa saja menjadi buruk. Apabila ledakan usia muda lebih dari 20\%, yang disebut sebagai "angka kritis" maka dapat memicu adanya tindakan korupsi dan ketidakstabilan politik, khususnya di negara yang memang angka korupsinya tinggi disebut dengan "kutukan" dari bonus demografi (Farzanegan \& Witthuhn, 2016).

Periode masa 'kanak-kanak' dan juga 'dewasa' merupakan istilah konotasi netral yang secara umum dipandang sebagai masa normatif dalam kehidupan. Sedangkan 'pemuda' dan 'remaja' biasanya memiliki berbagai permasalahan. Hal yang dimaksud adalah seperti kebebasan yang tak dapat dikendalikan, kekerasan, kurangnya tanggung jawab, ketidaksopanan, pemberontakan, mudah terluka/lemah, lalai, melanggar hak orang lain dan ketidakdewasaan. Bagi anak muda, istilah 'kriminal', 'penyimpangan', dan 'pelanggaran' menjadi perhatian khusus dari kebanyakan permasalahan perilaku ketimbang pada orang dewasa (Muncie, 2014).

Maka dari itu, pembinaan perlu dilakukan sebagai upaya untuk mengembangkan suasana kepemudaan yang sehat serta tanggap terhadap pembangunan masa depan yang akan meningkatkan kualitas pemuda yang berdaya guna dan berdaya saing tinggi ditengah kemajuan jaman yang pesat. Perlu adanya pemantapan fungsi dan peranan wadah bagi generasi muda seperti KNPI (Komite Nasional Pemuda Indonesia), Karang Taruna, OSIS (Organisasi Siswa Intra Sekolah), Pramuka, organisasi mahasiswa di lingkungan Perguruan Tinggi dan organisasi fungsional lainnya (Muslam, Fatkuroji, \& Muntoli'ah, 2016). Karang Taruna secara eksplisit merupakan wadah pembinaan dan pengembangan generasi muda yang aktif dalam pembangunan nasional serta dalam bidang kesejahteraan sosial dimana Karang Taruna sebagai salah satu wadah kreativitas generasi muda yang memiliki peranan sangat penting bagi tumbuh kembangnya kegiatan yang dilakukan (Muslam et al., 2016). 
Karang Taruna merupakan sebuah organisasi sosial masyarakat berbasis kepemudaan yang didirikan atas dasar kepedulian kaum muda terhadap permasalahan sosial yang terjadi di lingkungan masyarakat. Menurut Peraturan Mentersi Sosial Nomor 77/Huk/2010 tentang Pedoman Dasar Karang Taruna, Karang Taruna di definisikan sebagai organisasi sosial kemasyarakatan yang menjadi wadah dan sarana pengembangan setiap anggota masyarakat yang tumbuh dan berkembang atas dasar kesadaran dan tanggung jawab sosial dari, oleh dan untuk masyarakat terutama generasi muda di wilayah Desa/kelurahan yang bergerak dibidang usaha kesejahteraan sosial. Dalam kajian pendidikan kewarganegaraan, maka peran Karang Taruna masuk kepada implementasi dari gerakan community civic dan civic education movement yang bertujuan agar pendidikan kewarganegaraan lebih fungsional (Hepburn, 1997; Wuryan \& Syaifullah, 2008). Sedangkan dalam pembagian domain Pendidikan kewarganegaraan, peran Karang Taruna masuk dalam domain sosial kultural yang menekankan kepada konsep dan praksis Pendidikan kewarganegaraan di lingkungan masyarakat (Wahab \& Sapriya, 2011)

Berdasarkan uraian tersebut, permasalahan yang diangkat adalah "mengapa Karang Taruna berperan penting dalam mewujudkan tanggung jawab sosial pemuda sebagai gerakan warga negara?" Penelitian ini dilakukan pada Karang Taruna Nagasari Desa Sindanglaya Kec. Cipanas, Kab. Cianjur yang pada tahun 2016 mendapatkan juara 2 tingkat nasional sebagai Karang Taruna berprestasi, sehingga penelitian ini nantinya diharapkan dapat menghasilkan output berupa gambaran lengkap dan mendalam mengenai peranan Karang Taruna dalam mewujudkan tanggung jawab sosial pemuda, yang kemudian dapat dijadikan sebagai role model bagi Karang Taruna lain.

\section{Metode}

Pendekatan yang digunakan dalam penelitian ini adalah pendekatan kualitatif, yakni pendekatan penelitian yang lebih dalam membahas atau mengamati masalah-masalah sosial serta fenomena sosial dari sebuah kasus yang digambarkan melalui kata-kata dan penjabaran untuk mengungkap makna dibalik realitas (Al-Muchtar, 2016; Indrawan \& Yaniawati, 2016). Adapun metode yang digunakan adalah studi kasus, yang mengkhususkan kepada permasalahan pada situasi tertentu dan tempat tertentu yang kontekstual, mendalam dan terperinci terhadap seluruh subyek yang terkait dengan kelembagaan atau gejala tertentu yang ada di suatu daerah atau subyek yang terfokus (AlMuchtar, 2016) Subjek penelitian ini yaitu Karang Taruna Nagasari dengan penentuan informan dan juga key person menggunakan metode purposive sampling yang sengaja dipilih dengan berdasarkan pada pertimbangan tertentu (Al-Muchtar, 2016). Adapun informan pada penelitian ini yaitu Ketua Karang Taruna Nagasari, anggota, perwakilan pemuda, tokoh masyarakat, Kepala Desa serta perwakilan dari Pemerintah Daerah.

Desain penelitian ini adalah penelitian kualitatif deskriptif yang mengkhususkan pada interpretasi data serta penggambaran fenomena atau permasalahan sosial secara mendalam dengan mengumpulkan data yang berdasarkan kata kata (misalnya dengan wawancara), gambar (misalnya dari foto) dan pengamatan (misalnya dengan observasi) dari sejumlah kecil individu dan tempat guna dianalisis dan menginterprestasikan makna yang lebih besar dari temuannya (Creswell, 2010). Selain itu, penelitian dilakukan pada kondisi objek yang alamiah (sebagai lawannya adalah eksperimen) dimana peneliti adalah sebagai instrumen kunci, pengambilan sampel sumber dan data dilakukan secara purposive, teknik pengumpulan data dilakukan dengan triangulasi (gabungan) analisis data bersifat induktif / kualitatif, dan hasil penelitian yang lebih menekankan pada makna daripada generalisasi.

\section{Hasil dan Pembahasan}

Permasalahan tentang pemuda selalu menjadi pembahasan yang tidak ada habisnya, karena pada dasarnya issue yang berkenaan dengan pemuda merupakan hal yang bisa dibilang sangat krusial bagi perkembangan suatu bangsa, bahkan negara. Pemuda merupakan harapan bangsa dimana baik 
buruknya bangsa terletak di tangan mereka, jika pemudanya baik, maka niscaya bangsa tersebut akan baik, namun jika sebaliknya, maka kehancuran bangsa tersebut tinggal menunggu waktu saja (Widodo, 2017). Ibarat tunas, pemuda merupakan tunas muda yang siap menggantikan tanaman yang lama. Seperti hal nya daun teh yang selalu dipetik, atau rebung yang selalu diambil untuk dimasak, tunas muda akan terus tumbuh sebagai pengganti.

Kaum muda diasumsikan untuk mewujudkan masa depan dan perubahan secara kontinuitas, mereka sering menjadi pusat perhatian tentang bagaimana lokal, nasional, dan proses global berdampak pada negara dan bangsa (Bondy, 2016). Generasi mudan dibagi ke dalam usia persiapan masuk dunia kerja atau usia produktif antara 15-40 tahun (Irhandayaningsih, 2012). Sementara dari sudut pandang sosial budaya. Generasi muda dari sudut pandang ini memiliki sifat majemuk dengan aneka ragam etnis, agama, ekonomi, domisili, dan bahasa. Mereka memiliki ciri ekosistem kehidupan yang terbagi ke dalam masyarakat nelayan, petani, pertambangan, perdagangan, perkantoran dan sebagainya. Dengan jumlah atau ratio penduduk usia muda yang lebih banyak, tentu saja akan menjadi keuntungan bagi suatu negara. Karena dengan banyaknya jumlah usia produktif, maka hal tersebut dapat meningkatkan produktifitas di berbagai sektor seperti ekonomi, pendidikan, angkatan kerja, pembangunan dan lain sebagainya (Noor, 2015).

Banyak dari permasalahan bangsa yang ada saat ini diakibatkan oleh ketidakberdayaan pemerintah dan masyarakat yang mulai terpengaruh oleh faham asing, sehingga krisis multidimensional tidak dapat dihindarkan. Beberapa permasalahan kompleks yang saat ini sedang menimpa bangsa Indonesia, mulai dari isu HAM, pembalakan hutan, penangkapan ikan secara illegal, kekerasan terhadap anak, korupsi, demonstrasi anarkis serta kebakaran lahan yang belum bisa benar-benar diatasi (Andriani, 2016). Permasalahanpermasalahan tersebut tidak lepas dari bagaimana pendidikan karakter serta peran pemuda dalam menanggapi jati diri mereka sebagai kaum yang di masa depan akan menjadi seorang pemimpin dan juga penerus tongkat estafet generasi terdahulu.

Usia remaja atau pemuda sangat rentan dengan permasalahan sosial, sehingga tanggung jawab pemuda kepada masyarakat sangatlah besar, mengingat bahwa pemuda merupakan tonggak penerus estafet bangsa yang sangat krusial. Tanggung jawab sosial merupakan hal yang berkenaan dengan tindakan atau tingkah laku dan inisiatif untuk menghormati hak orang lain guna membentuk karakter warga negara yang bertanggung jawab dan menghindari kekerasan serta prilaku yang merusak (McDonough, UllrichFrench, Anderson-Butcher, Amorose, \& Riley, 2013). Tentunya dalam konteks berbangsa dan bernegara, sikap tangung jawab ini harus dimiliki oleh semua warga negara, terutama generasi muda untuk menekan apatisme terhadap lingkungan sekitar dan memupuk rasa tanggung jawab sosial kepada masyarakat. Salah satu upaya yang dilakukan guna membentuk tanggung jawab sosial generasi muda, salah satunya adalah dengan mengembangkan wadah berkumpul / organisasi bagi generasi muda yang dapat diwujudkan melalui peran serta organisasi yang berada di lingkungan pendidikan maupun masyarakat salah satunya yakni dengan mengikuti organisasi sosial Karang Taruna (Muslam et al., 2016).

Dalam konteks pendidikan kewarganegaraan, maka tanggung jawab sosial pemuda merupakan hal yang menjadi landasan dasar bagi mereka ketika terjun dalam lingkungan sosial masyarakat. Melalui pendidikan kewarganegaraan, pemuda diajarkan untuk tidak hanya menjadi warga negara yang aktif, dan bertanggung jawab secara individu, tetapi juga mereka harus bisa bertanggung jawab kepada keluarga, kepada masyarakat, dapat menghormati hak orang lain, dan mampu berinteraksi dengan masyarakat (Neufeld \& Davis, 2010; Wahab \& Sapriya, 2011). Pendidikan kewarganegaraan sebagai bidang keilmuan yang merupakan pengembangan dari tradisi ilmu sosial yakni transmisi kewarganegaraan yang berkembang menjadi struktur keilmuan 
yang dikenal dengan istilah "citizenship education" yang secara paradigmatik memiliki 3 domain, yakni : domain akademis (berbagai pemikiran pendidikan kewarganegaraan yang berkembang dalam lingkungan komunitas keilmuan), domain kurikuler (konsep dan praksis dari Pendidikan kewarganegaraan dalam dunia pendidikan), dan terakhir adalah domain sosial kultural (konsep dan praksis pendidikan kewarganegaraan di lingkungan masyarakat) (Wahab \& Sapriya, 2011).

Organisasi sosial masyarakat berbasis kepemudaan atau Karang Taruna tentunya merupakan salah satu wadah bagi pemuda untuk dapat berpartisipasi (civic engagement) sebagai warga negara dalam melayani masyarakat (service learning) untuk meningkatkan kepedulian dan tanggung jawab sosial mereka. Karena pada dasarnya Karang Taruna mampu menjadi agen perubah pemberdaya masyarakat untuk membangkitkan energi, inspirasi, antusiasme masyarakat, termasuk mengaktifkan, menstimulasi dan mengembangkan motivasi warga untuk bertindak (Arief \& Adi, 2014). Salah satu cara meningkatkan kesadaran ini yakni dengan memberikan materi terkait bagaimana hak dan kewajiban kita sebagai warga negara yang salah satunya kita dapatkan melalui Pendidikan kewarganegaraan, selain daripada rujukan lainnya mengenai service learning yang biasanya terintegrasi pada pendidikan politik, dan pendidikan ilmu politik, sebagai rumpun ilmu sosial sehingga mata pelajaran ini berfungsi sebagai pengantar bagi calon orang dewasa yang kelak menjadi warga negara yang tahu akan hak dan kewajibannya kelak.

Mengacu pada hal tersebut, gerakan warga negara pada dasarnya berkaitan dengan gerakan sosial, namun berbeda pada konteks dan tataran pengertian secara khusus. Gerakan sosial adalah tindakan kolektif yang diorganisir secara longgar, tanpa cara terlembaga untuk menghasilkan perubahan dalam masyarakat mereka (Sztompka, 2010). Berdasarkan pengertian tersebut, dapat disimpulkan bahwa gerakan sosial merupakan upaya mobilisasi yang dilakukan dengan sadar dan terencana untuk merubah suatu tatanan, aturan, maupun kebijakan politik secara menyeluruh berdasarkan kepentingan kelompok tertentu. Apabila gerakan sosial merupakan aksi untuk merubah suatu sistem, memobilisasi massa berdasarkan isu-isu konfliktual dan mengedepankan bentuk protes, maka gerakan warga negara lebih berfokus pada hakikat manusia sebagai warga negara, yakni lebih mengutamakan kepentingan bersama idak bertentangan secara konstitusi, dan lebih menekankan kepada partisipasi warga negara melalui organisasi dan gerakan dalam memberikan pengalaman serta praktik secara normatif dan ideologis sebagai pembentukan identitas kewarganegaraan yang konstruktif (Widjaja. H.A.W, 2000; Youniss, McLellan, \& Yates, 1997).

Karang Taruna Nagasari merupakan wadah pengembangan generasi muda Desa Sindanglaya yang didirikan pada tanggal 12 oktober 1985. Didirikannya karang taruna di Desa Sindanglaya karena didorong oleh semangat dan keinginan memajukan dan mensejahterakan masyarakat khususnya pemuda/remaja ditengah sumberdaya lokal yang serba terbatas. Adapun peran dari Karang Taruna Nagasari yaitu sebagai pelopor, penggerak, agen perubah dinamisator, fasilitator dan motivator bagi masyarakat Desa Sindanglaya terutama dalam pengembangan potensi sosial ekonomi dan penguatan nilai-nilai kearifan lokal seperti pemeliharaan tradisi budaya yang efektif mendorong peningkatan taraf kesejahteraan sosial masyarakat Sindanglaya, yang memiliki fungsi: (1) penyelenggaraan kesejahteraan sosial masyarakat Desa sindanglya; (2) penyelenggara pendidikan dan pelatihan bagi masyarakat terutama dibidang keagamaan; (3) penyelenggara pemberdayaan masyarakat, terutama generasi muda baik dibidang ekonomi maupun bidang sosial dan budaya; (4) pemelihara dan pengembang kesadaran tanggung jawab sosial generasi muda Desa Sindanglaya; (5) penumbuh kembang semangat kebersamaan yang memperkuat kesetiakawanan sosial dan persatuan pemuda Sindanglaya; (6) pemupuk kreatifitas generasi muda dengan 
mendayagunakan segala sumber dan potensi kesejahteraan sosial lokal secara swadaya.

Selanjutnya, ada 3 program utama dari Karang Taruna Nagasari yang menjadi unggulan, sekaligus menjadi bentuk tanggung jawab KT dalam pembentukan lingkungan sosial melalui pemberdayaan pemuda dan masyarakat yakni dalam bidang pelayanan kesejahteraan sosial yang meliputi: usaha kesejahteraan sosial rumah singgah sampah; pembinaan anak jalanan (anjal); car free day cipanas; pengobatan gratis untuk pmks; pendataan pmks secara rutin; santunan untuk anak yatim; pembagian sembako untuk warga miskin; kerja bakti pencegahan bencana longsor (penghijauan); kerja bakti membersihkan jalan dan lingkungan desa; bantuan swadaya tenaga dan barang untuk rutilahu; pembuatan dan pemeliharaan batas desa.

Dalam bidang pengembangan UEP (Usaha Ekonomi Produktif) dan KUBE (Kelompok Usaha Bersama), yang meliputi: janas fresh (pengembangan ekonomi mikro dalam bidang pertanian yang terfokus pada tanaman lettuce/selada), peternakan kelinci, dan bengkel las. Namun saat ini, Karang Taruna Nagasari memiliki tambahan pengembangan dalam bidang ekonomi yakni dengan memanfaatkan pembudidayaan ikan lele sangkuriang dan ikan nila, serta sayuran hidroponik yang berada di Karang Taruna unit Rw. 09 Desa Sindanglaya. Kemudian program yang terakhir adalah pengembangan Rekreatif, Olahraga dan Kesenian (ROK) meliputi: olahraga sepakbola, volly ball, karate, pencak silat, jalan santai, bulu tangkis, tenis meja, dll. Selain itu ada program lain yang menjadi rutinitas tiap tahun yakni perayaan hari-hari besar nasional dan keagamaan (khususnya hari besar Islam). Dengan kontinuitas serta komitmen para anggota Karang Taruna Nagasari masa bakti 2015-2018 dalam melaksanakan programprogram tersebut, khususnya pengentasan PMKS, Karang Taruna menuai banyak prestasi, diantaranya adalah: (1) pemuda pelopor tingkat Kabupaten tahun 2015; (2) diangkat sebagai pengawas tourism oleh KESBANGPOL Kabupaten Cianjur tahun 2015; (3) juara dalam pengelolaan tata ruang tingkat Desa se-kecamatan Cipanas tahun 2015; (4) diangkat sebagai satgas anti narkoba oleh BNNK tahun 2016; (5) juara Karang Taruna berprestasi tingkat Kabupaten tahun 2016; (6) juara Karang Taruna berprestasi tingkat Provinsi tahun 2016; (7) dan juara II Karang Taruna berprestasi tingkat nasional tahun 2016.

Hasil dari temuan dilapangan mengindikasikan bahwa Karang Taruna memiliki peranan yang sangat baik dalam pemberdayaan pemuda, memupuk rasa tanggung jawab sosial pemuda, serta membantu pemerintah daerah dalam menangani pengentasan Penyandang Masalah Kesejahteraan Sosial (PMKS) yang menjadi pokok daripada tujuan Karang Taruna dibentuk. Melihat bagaimana Karang Taruna Nagasari melaksanakan tugas sebagai wadah pemuda, berusaha memberdayakan masyarakat dan pemuda dengan ikhlas, tanpa pamrih, bahkan dengan pengorbanan yang tidak dapat dibilang sedikit, tergambar bahwa apa yang dilakukan mereka dapat dikatakan sebagai tri tugas sebagai manusia pembelajar, yang menekankan bahwa manusia dilahirkan dengan tiga tugas pokok utama : yaitu menjadi manusia pembelajar yang terus menerus di "sekolah besar" kehidupan nyata untuk semakin memanusiakan dirinya; kedua, menjadi pemimpin sejati dengan cara mengambil prakarsa dengan menerima tanggung jawab untuk menciptakan masa depan bagi dirinya, lingkungannya, perusahaan atau organisasi dimana ia bekerja; ketiga, bertumbuh bagi bangsanya, bagi bangsa-bangsa dan bagi umat manusia di "sekolah dasar" kehidupannya, hal inilah yang disebut sebagai tri tugas, tanggung jawab, dan kemanusiaan (the three tasks, responsibility, and humanity calling) (Harefa, 2008).

Pemberdayaan yang dilakukan oleh Karang Taruna Nagasari sangat bervariasi dan beranekaragam. Meskipun tidak dapat mengandalkan dana lebih untuk setiap kegiatan dan implementasi program, Karang Taruna Nagasari tetap berkomitmen dengan berdikari dan mengandalkan swadaya dari masyarakat serta bantuan dari desa. Beberapa program tersebut diantaranya telah memberdayakan banyak pemuda serta 
masyarakat yang mengalami permasalahan sosial seperti pengangguran, pengamen jalanan, putus sekolah, preman, kemiskinan dan lain sebagainya. Salah satu program tersebut yakni dengan membuka berbagai macam lapangan pekerjaan dan juga pemanfaatan potensi sumber daya alam yang bernilai ekonomis tinggi.

Dalam hal pengentasan masalah pemuda atau remaja yang mengalami masalah sosial di lingkungannya seperti pengangguran, pengamen jalanan dan para pemuda yang sering mabuk-mabukan, Karang Taruna Nagasari membuat program seperti pembinaan anak jalanan yang diberikan keterampilan khusus beserta sertifikat, kemudian Karang Taruna juga membuat semacam bengkel las yang mempekerjakan para pemuda yang belum mendapat pekerjaan tetap. Ada juga pemanfaatan bank sampah yang dikelola Karang Taruna untuk menanggulangi permasalahan sampah yang menumpuk di lingkungan desa. Kemudian dalam bidang usaha ekonomi produktif (UEP) Karang Taruna Nagasari memberikan opsi untuk menanam sayuran lettuce atau selada organik yang bernilai ekonomis tinggi guna menggantikan beberapa tanaman sayuran yang sebelumnya kurang begitu menjanjikan ketika masa panen tiba. Dengan menanam lettuce, masyarakat diharapkan dapat memperbaiki ekonomi mereka, karena harganya cukup tinggi. Saat ini program Jonas Fresh sudah menjalin kerjasama dengan beberapa perusahaan, salah satunya adalah perusahaan makanan cepat saji.

Selain itu, Karang Taruna Nagasari juga membuat tempat pembudidayaan lele sangkuriang serta ikan nila yang dilakukan secara swadaya oleh Karang Taruna unit beserta masyarakat untuk dikonsumsi bersama dan sebagian dijual. Ada juga program pembuatan material hidroponik dan aquaponik untuk menanam beberapa jenis sayuran seperti tomat hitam, lettuce dan lain sebagainya. Saat ini, hasil dari tanaman sayur hidroponik dan aquaponik ini masih sebatas pemanfaatan untuk konsumsi warga sekitar. Tak hanya itu, Karang Taruna Nagasari juga berusaha untuk berkontribusi terhadap lingkungan dengan membuat program penghijauan (tanam pohon) di wilayah yang menjadi langganan longsor. Kemudian dalam pengentasan masalah kemiskinan, Karang Taruna Nagasari juga bekerjasama dengan pihak Desa Sindanglaya untuk membangun sebuah rumah milik warga yang sudah tidak layak huni. Karang Taruna Nagasari juga memiliki program "cinta mayit" yang dilakukan guna membantu warga Desa Sindanglaya yang kurang mampu. Ketika ada sanak keluarga dari warga desa meninggal, gerakan cinta mayit yang digagas Karang Taruna ini menyediakan perlengkapan pemakaman secara gratis bagi warga, seperti kain kafan, mobil ambulance dan lain sebagainya.

Hal tersebut menunjukkan bahwa sebenarnya tanggung jawab sosial muncul dari setiap individu yang memiliki tujuan yang sama untuk mau bekerjasama dan menaruh empati terhadap sesama dengan cara bertindak sesuai kemampuan dan kapasitas yang dimiliki agar dapat berguna bagi orang lain. Tanggung jawab adalah ketika seseorang diberikan kekuatan dan kemampuan untuk melakukan sesuatu maka tanggung jawab merupakan sebuah kewajiban individu terhadap semua yang dilakukan, dimana tanggung jawab tersebut bersifat sangat pribadi dalam diri seseorang yang merasa maupun tidak merasakan setiap tanggung jawab dari apa yang mereka lakukan. Sehingga dapat disimpulkan bahwa tanggung jawab sesungguhnya adalah hal yang secara sadar maupun tidak sadar, merasa maupun tidak merasa, merupakan kewajiban bagi seseorang yang diberikan kemampuan dan juga kekuasaan ataupun kelebihan untuk menanggung setiap kegiatan, setiap tindakan, dan setiap langkah yang sudah dilakukan.

Untuk memaksimalkan peran pemuda, perlu adanya pemberdayaan, dimana pemberdayaan tersebut dapat digambarkan melalui teori analisis sosial pemberdayaan pemuda yang meliputi dimensi : (1) $a$ welcoming, safe environment (menyambut lingkungan yang aman), (2) meaningful participation and engagement (partisipasi dan keterlibatan yang bermakna), (3) equitable power-sharing between youth and adults (berbagi pengalaman yang layak antara 
pemuda dan orang dewasa), (4) engagement in critical reflection on interpersonal and sociopolitical processes (keikutsertaan dalam refleksi kritis pada proses interpersonal dan sosiopolitik), (5) participation in sociopolitical processes to affect change (partisipasi dalam proses sosiopolitik untuk membuat perubahan), and (6) integrated individual- and community-level empowerment (tingkatan pemberdayaan yang saling terintegrasi antara individu dengan masyarakat) (Jennings, Parra-Medina, Messias, \& McLoughlin, 2006). Karang Taruna Nagasari berusaha untuk menjalin kerjasama dan komunikasi pada tiap masingmasing individu untuk mau bergerak dan melakukan suatu perubahan yang dapat memunculkan rasa tanggung jawab serta kepedulian terhadap sesama. Tidak ada batasan antara yang tua dan yang muda, mereka saling bekerjasama untuk mengentaskan permasalahan yang terjadi di lingkungan sosial mereka.

Selain itu, hasil dari temuan di lapangan didapati bahwa konsep tanggung jawab sosial yang diterapkan oleh Karang Nagasari merupakan konsep pembentukan tanggung jawab yang didasari kepada: (1) tanggung jawab muncul dari dalam diri seperti DNA (natural), (2) kepedulian (careness), (3) empati (emphaty), (4) pengorbanan (sacrifice), (5) kemandirian (autonomy), dan (6) kerelaan untuk berjuang (willingness). Hal tersebut yang menjadi landasan bagaimana Karang Taruna Nagasari berperan membentuk pemuda yang memiliki tanggung jawab sosial.

Beberapa peran yang dilakukan Karang Taruna Nagasari dalam membentuk tanggung jawab sosial pemuda desa Sindanglaya, sebagai bagian dari warga Karang Taruna yakni : (1) mengajak pemuda untuk berperan aktif dalam organisasi Karang Taruna, (2) menanamkan sikap disiplin kepada setiap anggota untuk berkomitmen secara penuh dalam setiap kegiatan yang dilakukan dengan cara menghadiri perkumpulan paling tidak 2 kali dalam seminggu, (3) setiap anggota aktif Karang Taruna diharuskan mengerti tugas dan fungsi Karang Taruna, (4) setiap anggota Karang Taruna diharapkan untuk aktif di lingkungannya masing-masing, (5) setiap hasil yang diperoleh melalui program pemberdayaan masyarakat (yang merupakan inisisasi dari Karang Taruna) diusahakan untuk dikembalikan kepada masyarakat (seperti hasil pertanian, pengolahan sampah, hasil berternak dan lain sebagainya) sehingga masyarakat dapat merasakan manfaatnya, (6) setiap anggota diharapkan mengidentifikasi potensi di wilayahnya masing-masing, serta permasalahan sosial apa yang sedang terjadi, (7) adanya pembinaan terhadap calon ketua Karang Taruna selanjutnya melalui pendampingan dan arahan dari ketua Karang Taruna periode sebelumnya, (8) bersinergi dengan perangkat desa untuk memudahkan koordinasi, (9) merangkul para pemuda penyandang masalah kesejahteraan sosial (PMKS) untuk dibina dan diberdayakan.

Tanggung jawab sosial memiliki kriteria: (1) self-control and respect for the rights of others (kontrol diri dan menghormati hak orang lain); (2) effort and participation (usaha dan partisipiasi); (3) self-direction (pengarahan diri); and (4) helping others (membantu sesama) (Martinek, Schilling, \& Johnson, 2001). Melalui teori ini, didapati bahwa Karang Taruna Nagasari berperan dalam bagaimana cara mereka mengontrol diri dengan tidak egois dan lebih mementingkan kepentingan orang lain yang mengarah kepada sikap altruisme demi terciptanya kehidupan masyarakat yang sejahtera. Usaha dan partisipasi dari warga Karang Taruna, baik yang pasif maupun aktif sangat bersinergi, bahkan tingkat partisipasi pemuda untuk mengikuti Karang Taruna sangat tinggi. Hal tersebut didasari oleh rasa kebersamaan, empati, kepedulian, kerelaan untuk berjuang dan juga perasaan untuk ingin membantu satu sama lain.

Tentu saja hasil temuan di lapangan ini membuktikan bahwa Karang Taruna memiliki peranan penting dalam membentuk tanggung jawab sosial pemuda, karena dengan adanya Karang Taruna, dapat menjadi wadah untuk membantu sesama dan lingkungan. Tentu saja hal ini menjadi sangat penting mengingat bahwa, rasa tanggung jawab generasi muda saat ini kurang begitu tertanam dengan baik, mengingat bahwa jaman semakin maju dan tingkat individualistis makin tinggi, rasa 
tanggung jawab dan kepedulian terhadap sesama semakin kabur. Steinitz (1976) mengategorikan dilema tanggung jawab sosial ini kedalam 2 karakter dasar yakni: "self-made person" dan "good neighbour". Seseorang dengan karakter self-made person cenderung menganggap bahwa semua orang memiliki tanggung jawab moral yang sama terhadap orang lain, yang mana hal tersebut dapat menghancurkan inisiatif individu untuk membantu orang lain karena dia merasa bahwa tidak hanya kita yang memiliki kewajiban, namun orang lain juga sama. Sedangkan karakter good neighbour, merupakan karakter yang cenderung menganggap bahwa jangankan membantu orang lain, untuk berjuang dan bertahan hidup sendiri saja sulit.

Membantu orang lain hanya akan membuang waktu dan juga tenaga yang dapat mengakibatkan hidup semakin suram. Tentunya prilaku yang seperti ini bukan merupakan ciri dari bangsa Indonesia yang kental dengan nilai, budaya, adab serta gotong royong. Rasa peduli dan tanggung jawab sosial bukanlah harus dilakukan orang lain, atau menganggap bahwa membantu orang lain akan menambah kesusahan kita, justru dengan membantu orang lain, meskipun kita dalam keadaan susah, maka kita akan bermanfaat bagi sesama.

\section{Simpulan}

Karang Taruna Nagasari memiliki peranan dalam mewujudkan tanggung jawab sosial pemuda yang berada di Desa Sindanglaya. Program-program yang berkaitan dengan pengentasan masalah sosial masyarakat dan masalah pemuda dituangkan dalam program-program inovatif dan produktif seperti adanya pengembangan dalam bidang pelayanan kesejahteraan sosial seperti adanya pemberdayaan pemuda dan masyarakat, bidang pengembangan UEP (Usaha Ekonomi Produktif) dan KUBE (Kelompok Usaha Bersama), serta Olahraga dan Kesenian (ROK) yang terbukti membantu masyarakat dalam membentuk rasa tanggung jawab sosial pemuda untuk peduli terhadap lingkungan sosial nya.

\section{Ucapan Terima Kasih}

Tak pernah terlepas ucapan syukur dan rasa terimakasih terbesar penulis panjatkan kehadirat Allah SWT yang telah melimpahkan rahmat dan karunia-Nya kepada setiap hamba-Nya atas segala kelancaran yang diberikan. Kepada orang tua, kepada Ketua serta pengurus Karang Taruna Nagasari periode 2015-2018, Kepala Desa Sindanglaya, Pemerintah Daerah Kabupaten Cianjur, Universitas Pendidikan Indonesia, serta seluruh pihak yang terlibat dalam penelitian ini.

\section{Referensi}

Al-Muchtar, S. (2016). Dasar penelitian kualitatif. Bandung: Gelar Pustaka Mandiri.

Andriani, A. (2016). Melatif kearifan intelektual, emosional, dan spiritual pemuda guna menghadapi pasar bebas Asia Tenggara (Masyarakat Ekonomi Asean-MEA). JPIS, Jurnal Pendidikan Ilmu Sosial, 25(2), 15-20.

Arief, M. R., \& Adi, A. S. (2014). Peran karang taruna dalam pembinaan remaja di dusun candi Desa Candinegoro Kecamatan Wonoayu Kabupaten Sidoarjo. Kajian Moral dan Kewarganegaraan, 2(1), 190-205. Diambil dari http://ejournal.unesa.ac.id/index.php/jur nal-pendidikankewarganegaraa/article/view/6700

Bondy, J. M. (2016). Latina youth, education, and citizenship: A feminist transnational analysis. Theory and Research in Social Education, 44(2), 212-243. https://doi.org/10.1080/00933104.2016. 1170644

Creswell, J. W. (2010). Reseach design. Pendekatan, kualitatif, kuantitatif, dan mixed. Yogyakarta: Pustaka Pelajar.

Farzanegan, M. R., \& Witthuhn, S. (2016). Corruption and political stability: Does the youth bulge matter? European Journal of Political Economy, 49, 47-70. https://doi.org/10.1016/j.ejpoleco.2016. 12.007

Harefa, A. (2008). Menjadi manusia pembelajar. Jakarta: Kompas.

Hepburn, M. A. (1997). Service Learning in 
civic education: A concept with long, sturdy roots. Theory into Practice, 36, 136-142.

Indrawan, R., \& Yaniawati, P. (2016). Metodologi penelitian. Bandung: Refika Aditama.

Irhandayaningsih, A. (2012). Peranan Pancasila dalam menumbuhkan kesadaran nasionalisme generasi muda di era global. Humanika, 16(9), 1-10. https://doi.org/10.1016/S13596446(04)03042-9\rS1359644604030429 [pii]

Jennings, L. B., Parra-Medina, D. M., Messias, D. K. H., \& McLoughlin, K. (2006). Toward a critical social theory of youth empowerment. Journal of Community Practice, 14(1-2), 31-35. https://doi.org/10.1300/J125v14n01

Konadi, W., \& Iba, Z. (2011). Bonus demografi modal membangun bangsa yang sehat dan bermartabat. Majalah Ilmiah Unimus, 2(6), 18-24.

Martinek, T., Schilling, T., \& Johnson, D. (2001). Transferring personal and social responsibility of underserved youth to the classroom. The Urban Review, 33(1), 29-45.

McDonough, M. H., Ullrich-French, S., Anderson-Butcher, D., Amorose, A. J., \& Riley, A. (2013). Social responsibility among low-income youth in physical activity-based positive youth development programs: scale development and associations with social relationships. Journal of Applied Sport Psychology, 25(4), 431-447. https://doi.org/10.1080/10413200.2012. 751563

Muncie, J. (2014). Youth and crime. Youth and Crime (Second). London; California; New Delhi: Sage Publication. Muslam, Fatkuroji, \& Muntoli'ah. (2016). Pemberdayaan pemuda karang taruna melalui program remaja pintar berbasis agama desa wisata Kandri Kota Semarang. DIMAS, 16(1), 145-166. https://doi.org/http://dx.doi.org/10.2158 0/dms.2016.161.896

Neufeld, B., \& Davis, G. (2010). Civic respect, civic education, and the family. Educational Philosophy and Theory, 42(1), 94-111. https://doi.org/10.1111/j.14695812.2008.00506.x

Noor, M. (2015). Kebijakan pembangunan kependudukan dan bonus demografi. Serat Acitya - Jurnal Ilmiah UNTAG Semarang, 4(1), 121-128.

Steinitz, V. (1976). "People need help, but people take advantage" the dilemma of social responsibility for upwardly mobile youth. Youth \& Society, 7(4), 399-438. https://doi.org/10.1177/0044118X76007 00403

Suseno, F. M. (2015). Etika politik. Prinsipprinsip moral dasar kenegaraan maodern. Jakarta: Gramedia Pustaka Utama.

Sztompka, P. (2010). Sosiologi perubahan sosial. Jakarta: Prenada Media Group.

Wahab, A. A., \& Sapriya. (2011). Teori dan landasan pendidikan kewarganegaraan. Bandung: Alfabeta.

Widjaja. H.A.W. (2000). Penerapan nilainilai Pancasila \& HAM di Indonesia. Jakarta: PT. Rineka Cipta.

Widodo, S. K. (2017). Memaknai sumpah pemuda di era reformasi. HUMANIKA, 91(9), 399-404.

Wuryan, S., \& Syaifullah. (2008). Ilmu kewarganegaraan. Laboratorium PKn UPI.

Youniss, J., McLellan, J. A., \& Yates, M. (1997). What we know about engendering civic identity. American Behavioral Scientist, 40(5), 620-631. https://doi.org/10.1177/0002764297040 005008 